\title{
COMPARISON OF THE EFFECTIVENESS OF ANTIMICOTIC EXTRACT OF ETHANOL TEMU KUNCI AND TEMULAWAK ON CANDIDA ALBICANS
}

\author{
Mergivia Ekaristy $^{1)}$, Bernadette D Novita ${ }^{2)}$, Zenia Angelina ${ }^{3)}$
}

\begin{abstract}
Introduction: Candida albicans are normal flora bacteria on the skin and mucous membranes of humans. Candida albicans are said to be one of the causes of vaginal discharge or fluor albus. Temu kunci (Boesenbergia pandurata (Roxb.) Schlect) and temulawak (Curcuma xanthorrhiza Roxb) are the ingredients of herbal medicines with the potential as an antifungal.

Purpose: This study aims to explain the differences in the antifungal effect of the Temu kunci (Boesenbergia pandurata (Roxb.) Schlect) and Temulawak (Curcuma xanthorrhiza Roxb) extracts and explain how the combination of Temu kunci (Boesenbergia pandurata (Roxb.) Schlect) and Temulawak (Curcuma xanthorrhiza Roxb) extracts has an antifungal effect on Candida albicans by using the experimental study of post-test control group design.

Method: This study uses the Kirby-Baurer method and then measures the inhibitory zone by using calipers then comparing the inhibition zone of each extract.

Results: The research results show no difference in the effectiveness of each extract, and no inhibition zone was found for each extract.

Conclusion: This study concludes that the two extracts are not effective against C.albicans.
\end{abstract}

Keyword: Antifungal, Boesenbergia pandurata (Roxb.) Schlect, Curcuma xanthorrhiza Roxb, Candida albicans

\footnotetext{
${ }^{1)}$ Student of Faculty of Medicine, Widya Mandala Surabaya Catholic University Indonesia, J1. Kalisari Selatan No.1 Surabaya Email: immergiii26@gmail.com

${ }^{2)}$ Clinical Pharmacology Department, Faculty of Medicine, Widya Mandala Surabaya Catholic University Indonesia, J1. Kalisari Selatan No.1 Surabaya

${ }^{3)}$ Pediatric Department, Faculty of Medicine, Widya Mandala Surabaya Catholic University Indonesia, Jl. Kalisari Selatan No.1 Surabaya
} 


\section{INTRODUCTION}

Leucorrhoea or also called white discharge or vaginal discharge, or fluor albus, is a condition that can be both normal and pathological. Fluor albus complaints can occur in women of all ages. According to WHO (World Health Organization), almost all women have experienced vaginal discharge, $60 \%$ in adolescents (10-19 years) and $40 \%$ in women of childbearing age (20-46 years). According to research in Indonesia, 75\% of women experience vaginal discharge at least once in their lives, with $50 \%$ in adolescents and $25 \%$ in childbearing age.

Studies show that Candidia vulvovaginitis is most commonly diagnosed among young women, about 15$30 \%$ of the symptoms of women who visit a doctor. In comparison, the results of other studies of 50 samples of women of childbearing age in South Asia, especially India, stated $83 \%$ of the causes of fluor albus are Candida albicans.

C andida albicans live in humid environmental conditions. The natural environment of Indonesia, which is on the equator that makes it has a tropical climate, contributes greatly to the humidity of the air in Indonesia. Not only that, the condition of the female reproductive organs, which is a closed and folded area, so that if cleanliness is not maintained, it will easily become sweaty, damp, and dirty, and further increase the potential for candidiasis.

Because it is a normal flora, our bodies need Candida albicans, but when the condition of the body's immunity is down, this candida can grow too much and infects the human body. This is known as an opportunistic infection.

Women in Indonesia use herbal ingredients traditionally to treat fluor albus problems. Herbal medicinal ingredients that are known to have antifungal properties are Temu Kunci (Boesenbergia pandurata (Roxb.) Schlect) and Temulawak (Curcuma xanthorrhiza Roxb). This study aims to examine the effectiveness of ethanol extracts of temu kunci rhizomes and temulawak as an antifungal against Candida albicans by using an experimental research of post-test control group design.

\section{METHOD}

The method used was the agar plate diffusion method (Kirby-Bauer) which is categorized as a direct sensitivity test method. Six petri of Sabaroud Glucose-2\% jelly was prepared. Candida albicans were taken from the preparation and scratched using a cotton swab on the surface of Sabaroud Glucose-2\% jelly. Paper disc was formed by using seventeen 
perforators before dropped with the extract. The paper disc was first sterilized by heating in an oven at $70 \mathrm{oC}$ for 15 minutes; five of them were given temu kunci extract, five more were given temulawak extract, five of them were mixed extract of temu kunci and temulawak, one was given $2 \%$ DMSO as a negative control, and a paper disc containing $2 \%$ ketoconazole as positive control by dropping as much as $1.5 \mathrm{ml}$ and left for 15 minutes before sticking to agar. The paper disc was then placed on Sabaroud Glucose-2\% agar which had been scratched with Candida albicans, then incubated for 48 hours at $37^{\circ} \mathrm{C}$. Inhibitory zone diameters seen as clear zones are measured using calipers.

\section{RESULTS}

\section{Table 1 Phytochemical Screening}

\begin{tabular}{|lllll|}
\hline Treatment & $\begin{array}{l}\text { Secondary } \\
\text { metabolite }\end{array}$ & Reactor & Result & information \\
\hline Temu Kunci & Flavonoids & $\begin{array}{l}\mathrm{Mg}+\mathrm{HCl} \\
\text { pekat }\end{array}$ & + & $\begin{array}{l}\text { Tomato red } \\
\text { like color }\end{array}$ \\
\hline & Saponins & Aquades & + & Foam \\
\hline & Tannins & $\mathrm{FeCl}_{3}$ & + & $\begin{array}{l}\text { Blackish } \\
\text { green color }\end{array}$ \\
\hline & $\begin{array}{l}\text { essential } \\
\text { oils }\end{array}$ & $\begin{array}{l}\text { Vanilin } \\
\text { sulfat }\end{array}$ & + & Stained \\
\hline Temulawak & Flavonoids & $\begin{array}{l}\mathrm{Mg}+\mathrm{HCl} \\
\text { pekat }\end{array}$ & + & $\begin{array}{l}\text { Tomato red } \\
\text { like color }\end{array}$ \\
\hline & Saponins & Aquades & + & Foam \\
\hline & Tannins & $\begin{array}{l}\mathrm{FeCl} \\
\text { Banch }\end{array}$ & + & $\begin{array}{l}\text { Blackish } \\
\text { green color }\end{array}$ \\
\hline & $\begin{array}{l}\text { essential } \\
\text { oils }\end{array}$ & $\begin{array}{l}\text { Vanilin } \\
\text { sulfat }\end{array}$ & + & Stained \\
\hline
\end{tabular}

In phytochemical screening, temu kunci and temulawak extract positively contain flavonoids, saponins, tannins, and essential oils.
Table 2 Anti-fungal Activity Test

\begin{tabular}{|c|c|c|c|c|c|c|c|}
\hline \multirow[t]{3}{*}{ Treatment } & \multirow{3}{*}{$\begin{array}{l}\text { Concent } \\
\text { ration }\end{array}$} & \multicolumn{5}{|c|}{ Inhibitory zone (mm) } & \multirow{3}{*}{$\begin{array}{l}\text { Ave } \\
\text { rage }\end{array}$} \\
\hline & & $\mathrm{Uj}$ & $\mathrm{Uj}$ & $\mathrm{Uj}$ & $\mathrm{Uj}$ & Uji & \\
\hline & & i 1 & i 2 & i 3 & i 4 & 5 & \\
\hline \multirow[t]{5}{*}{ Temulawak } & $40 \%$ & 0 & 0 & 0 & 0 & 0 & 0 \\
\hline & $30 \%$ & 0 & 0 & 0 & 0 & 0 & 0 \\
\hline & $20 \%$ & 0 & 0 & 0 & 0 & 0 & 0 \\
\hline & $10 \%$ & 0 & 0 & 0 & 0 & 0 & 0 \\
\hline & $5 \%$ & 0 & 0 & 0 & 0 & 0 & 0 \\
\hline \multirow[t]{5}{*}{ Temu kunci } & $40 \%$ & 0 & 0 & 0 & 0 & 0 & 0 \\
\hline & $30 \%$ & 0 & 0 & 0 & 0 & 0 & 0 \\
\hline & $20 \%$ & 0 & 0 & 0 & 0 & 0 & 0 \\
\hline & $10 \%$ & 0 & 0 & 0 & 0 & 0 & 0 \\
\hline & $5 \%$ & 0 & 0 & 0 & 0 & 0 & 0 \\
\hline \multirow[t]{5}{*}{ Mixture } & $40 \%$ & 0 & 0 & 0 & 0 & 0 & 0 \\
\hline & $30 \%$ & 0 & 0 & 0 & 0 & 0 & 0 \\
\hline & $20 \%$ & 0 & 0 & 0 & 0 & 0 & 0 \\
\hline & $10 \%$ & 0 & 0 & 0 & 0 & 0 & 0 \\
\hline & $5 \%$ & 0 & 0 & 0 & 0 & 0 & 0 \\
\hline $\begin{array}{l}\text { Positive } \\
\text { control }\end{array}$ & $2 \%$ & $\begin{array}{r}24 \\
, 6\end{array}$ & $\begin{array}{l}26 \\
, 4\end{array}$ & $\begin{array}{c}22 \\
, 3\end{array}$ & $\begin{array}{c}24 \\
, 7\end{array}$ & $\begin{array}{c}25, \\
5\end{array}$ & 24,7 \\
\hline $\begin{array}{l}\text { Negative } \\
\text { control }\end{array}$ & $2 \%$ & 0 & 0 & 0 & 0 & 0 & 0 \\
\hline
\end{tabular}

Table 2 shows the diameters of the Candida albicans ATCC 10231 inhibition zones in various extract concentrations and tested by the KirbyBauer method. This method is commonly used in anti-fungal power tests because it is more effective at inhibiting the growth of large fungi. This method can determine the extent of the inhibition zone. Inhibition zone diameters are indicative of the sensitivity of the test fungus. The wider the inhibition zone, the better anti-fungal power. This method also makes it easier to 
compare the diameter of inhibition zones between extracts.

\section{DISCUSSION}

The anti-fungal activity test of temulawak ethanol extract and temu kunci ethanol extract against C. Albicans at concentrations of $40 \%, 30 \%, 20 \%, 10 \%$, and 5\% shown no inhibitory zones formed. In addition, control treatments were also carried out, with $2 \%$ ketoconazole as a positive control and $2 \%$ DMSO as a negative control. Ketoconazole was chosen because it is the azole group that is the best in inhibiting C. albicans.

Ethanol extract of temu kunci and temulawak can't inhibit the growth of C. Albicans. Meanwhile, the positive control using ketoconazole can inhibit the growth of C. Albicans. This is thought to be due to compounds contained in temu kunci, and temulawak rhizome extract could not inhibit the synthesis of ergosterol in C. Albicans cell membranes as well as in ketoconazole.

Flavonoids can form complex compounds of extracellular proteins that interfere with the integrity of the fungal cell membrane by disrupting the lipid layer, and the cell wall will be damaged, and can disrupt cell metabolism by inhibiting nutrient transport. Saponins can lyse microbial cell membranes and inhibit
DNA polymerase so that nucleic acid synthesis is interrupted. ${ }^{4,5,6}$ Tannins and essential oils work in the same way to inhibit the formation of the enzyme C-14 demethylase, which plays a role in ergosterol synthesis and inhibits chitin synthesis in cell walls . .,8,9 $^{7,}$

Even though it contains flavonoids, saponins, tannins, and essential oils extracting temu kunci and temulawak do not have inhibitory zones as antifungals in the growth of C. Albicans. This is presumed because the amount of the secondary metabolite compound that has been mentioned is inadequate to inhibit $\mathrm{C}$. Albicans' growth. Phytochemical screening conducted in this study can only prove a secondary metabolite compound qualitatively, not quantitatively. The content of secondary metabolite compounds in plants that grow in areas with high water availability is less than plants in drier areas.

\section{CONCLUSION}

From the results of the study with the title "Comparison of the Effectiveness of Antimicotic Extract of Ethanol Temu Kunci And Temulawak On Candida Albicans" which was carried out on September 6 - October 27, 2019, it can be concluded that there is no difference in anti-fungal effectiveness between temu 
kunci and temulawak towards Candida albicans because on the results of both studies the extract was declared ineffective. And the mixture of temu kunci and temulawak extract has no anti-fungal effect on Candida albicans.

\section{REFERENCES}

1. Amanah, A., Fadhil, N., Lazuardi, M., \& Hermawan, I. (2018). Perbandingan Efektivitas Minyak Atsiri Daun Sirih Hijau ( Piper betle Linn ) dengan Minyak Atsiri Rimpang Temulawak ( Curcuma xanthorrhiza ) terhadap Candida albicans secara In Vitro. 89-96.

2. Mardalena, Ria Mistika. (2015). Hubungan Pengetahuan dan Sikap dengan Tindakan Kebersihan Organ Genitalia Eksterna Sebagai Upaya Pencegahan Keputihan Pada Mahasiswi Angkatan 2013 di Fakultas Kesehatan Masyarakat USU Medan Tahun 2015. Retrieved from http://repository.usu.ac.id

3. Brunton LL, Parker KL, Blumenthal DK, Buxton ILO. Goodman and Gilman's manual of pharmacology and theurapeutics. Jakarta: EGC. 2010.

4. Badal, Simon RD. Pharmacognosy: Fundamentals,
Applications and Strategy. United Kingdom: Academic Press; 2017.

5. Robinson, T., 1995, Kandungan Organik Tumbuhan Tinggi, Edisi VI, Hal 191-216, Diterjemahkan oleh Kosasih Padmawinata, ITB, Bandung.

6. Chahyadi, A., Hartati, R., Wirasutisna, K. R., \& Elfahmi. (2014). Boesenbergia Pandurata Roxb., An Indonesian Medicinal Plant: Phytochemistry, Biological Activity, Plant Biotechnology. Procedia Chemistry, 13, 13-37. https://doi.org/10.1016/j.proche.20 14.12.003

7. Nurhafani F. Perbandingan potensi antimikroba ekstrak n-heksana daun kelor (Moringa oleifera) dengan kulit biji (pericarp) jambu mete (Anacardium occidentale) terhadap bakteri Pseudonomonas aeruginosa. [Skripsi]. Malang: Universitas Brawijaya; 2012.

8. Davidson MW. Saponin. [internet] 2004.

http://micro.magnet.fsu.edu/phytoc hemicals/pages/saponin.html,. Diakses pada 30 Oktober 2019.

9. Lingga ME dan Rustama MM. Uji aktivitas antibakteri dari ekstrak air dan etanol bawang putih (Allium sativum L.) terhadap bakteri Gram negatif dan Gram positif yang 
diisolasi dari udang dogol (Metapenaeus monoceros), udang lobster (Panulirus sp.) dan udang rebon (Mysis dan Acetes). [internet]. Jurnal Biotika. 2005. 